sums up the situation thus: (1) the microbe Doyen exists; (2) it is probably secondary, as streptococci, \&c., are found in tuberculous cavities, and is not the cause of cancer; and (3) the serum obtained by its aid does sometimes ameliorate the condition of cancer patients in the same way that amelioration may sometimes be obtained by injection of sera obtained from other organisms.

I am, Sirs, yours faithfully,

April 3rd, 1905. R. Stenhouse Willinds, M.B. Edin., \&c.

\section{MEDICINE: ITS PRACTICE AND ITS PUBLIC RELATIONS.}

To the Editors of THE LANCET.

SIRs,-Referring to your remarks made in Chapter VI. (p. 879) of "Medicine: its Practice and its Public Relations," with reference to the action of the Pharmaceutical Society against members of the medical profession in Scotland for the infringement of the Pharmacy Acts by their unqualified assistants in pharmacy, you do not seem to be aware that we appealed to the Privy Council, complaining of the action of the General Medical Council. That petition was sent by the Privy Council to the General Medical Council who recorded it in their minutes (1903 or 1904). The Pharmaceutical Society has not ceased action, as it has prosecuted a number of unqualified assistants of medical practitioners for the sale of poisons and I think in every case has obtained penalties. The General Medical Council, however, has taken no action in these cases. What is the reason of this I do not know. I am, Sirs, yours faithfully,

Glasgow, April 3rd, 1905. JoHN BRown, M.D., F.F.P.S. Glasg.

\section{To the Editors of THE LANCET.}

SIRs,-Referring to the fifth very able article of your correspondent on "Medicine: its Practice and its Public Relations," I should like to point out, as a hospital reformer of some years' standing, that bare justice has been done only in relation to the hospital conference which was held at St. Martin's Hall in October, 1899. I was, of course, not responsible in any way for the speeches made on that occasion but I was altogether responsible for the various papers read. And I venture to say without any diffidence that the authors of the various papers were men who had had great experience of the subjects they wrote about; and, moreover, although many years have passed since their views were published, yet nothing fresh in any way has been given to the world with regard to the solutions of the many problems that they dealt with individually. I may be allowed to add that some of the recommendations made by the authors of the papers have been adopted by the authorities of the various metropolitan hospital funds. I may be pardoned for recalling to your memory the names of those gentlemen who so materially assisted at the conference by reading papers: Dr. F. J. Smith, Mr. Douglas Dent, Dr. Arnold W. W. Lea, Mr. G. Hawkins-Ambler, Colonel Montefiore, Mr. G. A. Wright, Dr. Bertram M. H. Rogers, and Mr. C. W. Warren.

$$
\text { I am, Sirs, yours faithfully, }
$$

Cardiff, March 29th, 1905.

\section{T. GARRETT HORDER.}

\section{To the Editors of THE LANCET.}

SrRs,-I am obliged to you for allowing me to see these letters. Some of the names which $\mathrm{Mr}$. Horder enumerates belong to gentlemen honourably known for their work and far be it from me to suggest that they or any other speakers did not know their subject au fond. All that I intended to convey was that certain of the speeches did not bear out this view.

I knew, of course, of the action of the Privy Council but not of the continued prosecutions to which Dr. Brown alludes. I am, Sirs, yours faithfully, THE AUTHOR OF THE ARTICLES.

\section{THE RATIONAL TREATMENT OF FRACTURES.}

To the Eatitors of THE LANCET.

SIRS, - In THE LANCET of March 4th, p. 601, "Dubitans," in the course of commenting on the method of treating fractures, as strapping, rubbing, and movement, asks me two questions. First, as to whether I should use extensiun in the case of oblique fracture of the bones of the leg-i.e., the femur, the tibia, and the fibula-I would in reply say that in fractures of the femur I like to use, and have up to now found efficient, the double inclined plane or Liston's long splint with perineal band, according to the position of the fracture, but in either case following out the strapping, rubbing, and movement. As regards the fracture of both bones of the leg the case which I described was oblique in nature and did very well with strapping and Cline splints. I certainly am of opinion that strapping helps to hold the bones in position and checks riding to a great extent. In a bad case of oblique fracture of this kind, if I found Cline splints and strapping were insufficient to keep them in position, I should place the limb, after strapping, on a back splint with side splints and sling it in a Salter's cradle. Personally I seldom try to adjust the position of a bad fracture at once accurately, as it is far better to wait until the inflammatory effusion has settled to some extent and is beginning to be absorbed. Rubbing will hasten this greatly. By delaying the "setting" in this manner for some days the spasmodie contraction of the muscles will have subsided to a great degree. It is quite possible that one might see a very oblique fracture that would get out of position directly a splint is removed. If $I$ were to find a fracture do this in spite of the strapping I should not remove the restraining influences until some union had occurred but were this fracture in a position to allow the joints above and below to be used daily while supporting the fracture with short splints I should certainly make use of some form of splint which would permit the joints to be moved and begin rubbing as soon as there was some degree of union.

The second question is as to whether the generalisation of so-called rational treatment from simple cases of fracture is dangerous when applied indiscriminately elsewhere and is there any other rational treatment in the troublesome cases than bone carpentry by cutting down upon, and securing together, the fragments, as in Mr. W. A. Lane's plan? As to the first half of this question, the term rational treatment was not meant to be dogmatic and if taken in the narrower sense might be dangerous. As regards the bone carpentry I admit that there may be some cases of oblique fracture where, in spite of all the care possible, the result will still be unsatisfactory.

I believe that in these cases Mr. Lane's treatment is the right one but $I$ do not think that this method can be of general use in practice. The operations are not so easy in the most happy circumstances and would be practically impossible to carry out and to keep aseptic in many small houses and cottages, even supposing the patients were willing to allow it. In country districts the patients will solve the problem for one. They are not likely easily to submit to "an operation for a broken bone" as they would term it. You would probably find yourself dismissed in favour of a surgeon who has not expressed any desire to use the knife to mend the leg; and from the surgeon's point of view I think this is an operation which should only be undertaken in aseptic surroundings and patients are loth to leave their homes for hospitals on account of broken limbs. Even among the better classes where the surroundings are suitable I think that there would be an almost insuperable objection on their part to operation on simple fractures. In compound fractures this objection would not be so great. Circumstances alter cases and what might be the rational treatment in one case would be quite unsuitable in the other, and fortunate is the surgeon who can adapt himself to the surroundings of each individual case; but I certainly maintain that the rational treatment of any fracture, where it is possible to use it, is by the method of strapping, rubbing, and movement, as early as possible, consistent with a good result.

March 17th, 1905

I am, Sirs, yours faithfully,

\section{IF TUBERCULOSIS SHOULD BE CERTIFIED, WHY NOT SYPHILIS? \\ 7o the Editors of THE LANCET.}

SIRS, - I never heard of phthisis causing syphilis but I believe that many thousands of cases of phthi is are caused by syphilis. And considering that there are thousands of cases in our lunatic asylums caused by syphilis and that our hospitals have thousands of cases of heart and kidney 